\title{
Upaya Meningkatkan Hasil Belajar Kimia melalui Model Pembelajaran Inquiri pada Materi Metode Ilmiah
}

\author{
I Putu Gede Anom ${ }^{1^{*}}$ \\ ${ }^{1}$ SMA Negeri 1 Kuta Utara. Bali, Indonesia
}

\section{A R T I C L E I N F O}

Article history:

Received 20 October 2020

Received in revised form

30 November 2020

Accepted 10 January 2021

Available online 01

February 2021

Kata Kunci:

Inquiri, Hasil Belajar

Keywords:

Inquiry, Learning Result

\begin{abstract}
A B S T R A K
Rendahnya hasil belajar siswa disebabkan karena banyak guru mengajar tanpa membawa persiapan sama sekali. Penelitian ini bertujuan untuk menganalisis pengaruh penerapan Model Pembelajaran Inquiri terhadap hasil belajar kimia kelas X IPA 4. Penelitian ini termasuk penelitian Tindakan kelas. Metode pengumpulan data yang digunakan pada penelitian ini adalah tes prestasi belajar. Metode analisis data yang digunakan adalah deskriptif. Subjek penelitian ini adalah siswa kelas $\mathrm{X}$ IPA 4 yang berjumlah 42 orang. Hasil yang diperoleh dari penelitian ini adalah Model Pembelajaran Inquiri dapat meningkatkan hasil belajar kimia kelas X IPA 4 semester 1 SMA Negeri 1 Kuta Utara tahun pelajaran 2017/2018. Ini terbukti dari hasil yang diperoleh pada Awalnya rata-rata 54,26, Siklus I naik menjadi 66,21 dan pada Siklus II naik menjadi 81,31 . Kesimpulan yang diperoleh dari penelitian ini adalah Model Pembelajaran Inquiri dapat meningkatkan hasil belajar kimia kelas X IPA 4 semester 1. Implikasi penelitian ini memberikan dampak meningkatkan keaktifan siswa dalam belajar dan menciptakan suasana pembelajaran yang menyenangkan, siswa dapat bekerja sama satu sama lain sehingga model ini dapat meningkatkan hasil belajar Kimia.
\end{abstract}

A B S T R A K

The low student learning outcomes are because many teachers teach without bringing any preparation at all. This study aims to analyze the effect of the application of the Inquiry Learning Model on the learning outcomes of chemistry class X IPA 4. This research is classroom action research. Method. Inquiry, learning outcomes data collection used in this study is a learning achievement test. The data analysis method used is descriptive. The subjects of this study were 42 students of class $X$ IPA 4. The results obtained from this study are that the Inquiry Learning Model can improve learning outcomes in chemistry class X IPA 4 semester 1 SMA Negeri 1 North Kuta in the 2017/2018 school year. This is evident from the results obtained at the initial average of 54.26, in Cycle I it increased to 66.21 and in Cycle II it increased to 81.31. The conclusion obtained from this research is that the Inquiry Learning Model can improve learning outcomes of chemistry class X IPA 4 semesters 1 . The implication of this research has an impact on increasing student activity in learning and creating a pleasant learning atmosphere, students can work together with each other so that this model can improve chemistry learning outcomes.

\section{Pendahuluan}

Pentingnya pendidikan bagi kehidupan bangsa dan negara membuat bangsa Indonesia melakukan berbagai upaya untuk meningkatkan kualitas pendidikan. Upaya-upaya tersebut antara lain menyusun dan menyempurnakan kurikulum, meningkatkan sarana dan prasarana belajar, melaksanakan penataran guru, untuk tercapainya tujuan pendidikan nasional yaitu meningkatkan kualitas manusia indonesia,manusia seutuhnya yang beriman dan bertaqwa kepada Tuhan Yang Maha Esa, berbudi pekerti luhur, berkepribadian, berdisiplin, bekerja keras, tangguh, mandiri, cerdas, bertanggungjawab dan terampil serta sehat jasmani dan rohani,juga harus mampu menumbuhkan dan memperdalam rasa cinta

Copyright (C) Universitas Pendidikan Ganesha. All rights reserved 
terhadap tanah air ,mempertebal semangat kebangsaan dan rasa kesetiakawanan sosial. Pendidikan akan mengupayakan kehidupan kearah yang lebih baik dan diperlukan untuk di masa yang akan datang (Jaedun \& Nuryadin, 2017; Renny, Sonbay, Yohana, 2019). Dalam proses belajar mengajar guru memegang peranan yang sangat penting yaitu membantu siswa belajar untuk meningkatkan hasil belajar. Karena itu guru harus dapat membuat suatu pengajaran menjadi lebih efektif dengan memilih metode dan model pembelajaran yang sesuai untuk meningkatkan sikap ilmiah,aktifitas dan hasil belajar siswa (Febriana, 2017; Rediasih, Suwatra, \& Putri, 2019). Pembelajaran di kelas berlangsung baik apabila guru beprilaku profesional. Dalam menjalankan tugasnya guru harus bertanggung jawab dan selalu mengadakan inovasi-inovasi yaitu mampu menerapkan strategi pembelajaran dengan baik dan memiliki inovasi yang lebih baik (R. S. Dewi, 2018; Wahyono, Husamah, \& Budi, 2020). Untuk itu guru semestinya memahami materi pelajaran termasuk memahami peran, fungsi dan kegunaan mata pelajaran yang diampu.

Permasalahan yang sering terjadi saat ini adalah guru kurang mampu mengadakan inovasiinovasi dalam pembelajaran yang mampu meningkatkan minat siswa dalam belajar. Penelitian yang dilakukan oleh Rani, Ardana, \& Negara (2019) dan Wulandari, Sudatha, \& Simamora (2020) menyatakan bahwa masih banyak guru yang belum menerapkan model pembelajaran inovatif dalam belajar sehingga banyak siswa yang belum memahami materi pembelajaran. Penelitian yang dilakukan oleh Anika \& Fajar (2020) menyatakan bahwa guru lebih dominan mengajar dengan metode konvensional seperti ceramah sehingga siswa merasa bosan dalam belajar. Kebiasaan-kebiasaan guru mengajar tanpa membuat persiapan yang baik menjadi kendala bagi kemajuan pendidikan di Indonesia (Ardiawan, 2020; Kristiantari, 2015). Banyak guru mengajar tanpa membawa persiapan sama sekali. Praktek-praktek pendidikan semacam ini terus berlangsung lama bahkan sampai sekarang. Hal semacam ini menuntun pendidikan kearah yang semakin hari semakin lebih jelek. Dalam keadaan yang semacam ini, pemerintah perlu turun tangan untuk memberi dorongan pada guru-guru untuk melakukan pembelajaran sesuai teori-teori baru. Permasalahan ini juga ditemukan pada salah satu sekolah dasar. Berdasarkan hasil observasi di SMA Negeri 1 Kuta Utara ditemukan beberapa permasalahan yaitu hasil belajar Kimia siswa yang rendah. Hasil belajar Kimia pada siswa kelas mencapai rata-rata sebesar 54,26. Dari rata-rata tersebut, ada 35 peserta didik memperoleh nilai dibawah KKM, ada 7 orang peserta didik yang mencapai KKM untuk mata pelajaran kimia. Rendahnya hasil belajar tersebut disebabkan guru kurang menerapkan metode dan model pembelajaran yang inovatif dalam pembelajaran. Kondisi tersebut juga disebabkan oleh beberapa faktor yaitu: a) cara pengajaran guru masih konvensional, guru masih mendominasi pembelajaran sehingga peserta didik lebih banyak menunggu. Banyak siswa yang merasa bosan jika guru menggunakan metode ceramah dalam proses pembelajaran sehingga siswa kurang menyerap pembelajaran. Permasalahan ini berdampak pada hasil belajar siswa yang rendah. Dapat diketahui hal-hal yang perlu dalam upaya meningkatkan aktivitas dan prestasi belajar peserta didik seperti penguasaan metode dan model pembelajaran, penguasaan teori belajar, penguasaan teknik tertentu, penguasaan peran, fungsi serta kegunaan mata pelajaran. Apabila betul-betul guru menguasai dan mengerti tentang hal-hal tersebut dapat diyakini bahwa prestasi belajar peserta didik pada mata pelajaran kimia tidak rendah.

Keterampilan yang mesti dikuasai guru dalam melaksanakan pembelajaran ada 7, yaitu: 1) keterampilan bertanya, 2) keterampilan memberi penguatan, 3) keterampilan mengadakan variasi, 4) keterampilan menjelaskan, 5) keterampilan membuka dan menutup pelajaran, 6) keterampilan membimbing diskusi, 7) keterampilan mengelola kelas (Damanik \& Anggaraeni, 2018; Oktiani, 2017). Keterampilan-keterampilan ini berhubung dengan kemampuan guru untuk menguasai dasar-dasar pengetahuan yang berhubungan dengan persiapan dan pelaksanaan proses pembelajaran yang bisa memberikan dukungan terhadap cara berpikir peserta didik yang kreatif dan imajinatif. Hal inilah yang menunjukkan profesionalisme guru. Melihat kesenjangan antara harapan dengan kenyataan lapangan sangat jauh berbeda, agar masalah ini tidak berlarut-larut dan segera dapat dipecahkan dalam upaya memperbaiki mutu pendidikan utamanya pada mata pelajaran kimia, sangat perlu kiranya dilakukan perbaikan cara pembelajaran. Salah satunya adalah dengan menerapkan model pembelajaran inovatif yang dapat memotivasi siswa dalam belajar. Penggunaan model-model pembelajaran juga merupakan hal yang sangat penting dalam upaya meningkatkan hasil belajar siswa (Juniati \& Widiana., 2017; Widiartini, Putra, \& Manuaba, 2018). Model sangat berkaitan dengan teori. Model merupakan suatu analog konseptual yang digunakan untuk menyarankan bagaimana meneruskan penelitian empiris sebaiknya tentang suatu masalah. Jadi model merupakan suatu struktur konseptual yang telah berhasil dikembangkan dalam suatu bidang dan sekarang diterapkan, terutama untuk membimbing penelitian dan berpikir dalam bidang lain, biasanya dalam bidang yang belum begitu berkembang. Salah satu model pembelajaran inovatif adalah model pembelajaran inquiri. Penelitian yang dilakukan oleh Andoko (2020) menyatakan bahwa model pembelajaran inquiri dapat meningkatkan keaktifan siswa dalam belajar 
sehingga berpengaruh pada hasil belajar siswa yang meningkat. Penelitian yang dilakukan oleh Suratijo (2015) menyatakan bahwa penggunaan model pembelajaran inquiri dapat meningkatkan aktivitas belajar siswa sehingga berdampak positif pada hasil belajar siswa.

Pembelajaran inkuiri menekankan kepada proses mencari dan menemukan. Materi pelajaran tidak diberikan secara langsung. Peran siswa dalam pembelajaran ini adalah mencari dan menemukan sendiri materi pelajaran, sedangkan guru berperan sebagai fasilitator dan pembimbing siswa untuk belajar (Budiartini, Arcana, \& Margunayasa, 2013; Sukarmen, 2019). Pembelajaran inkuiri merupakan rangkaian kegiatan pembelajaran yang menekankan pada proses berpikir kritis dan analitis untuk mencari dan menemukan sendiri jawaban dari suatu masalah yang dipertanyakan (Fitriana, Lesmanawati, \& Maknun, 2014; Sumiarta, Murda, \& Rati, 2013). Model pembelajaran inquiri adalah merupakan kegiatan pembelajaran yang melibatkan secara maksimal seluruh kemampuan siswa untuk mencari dan menyelidiki sesuatu (benda, manusia atau peristiwa) secara sistematis, kritis, logis, analitis sehingga mereka dapat merumuskan sendiri penemuannya dengan penuh percaya diri (Budiartini et al., 2013; Suratijo, 2015). Dengan model pembelajaran inquiri ini diharapkan mampu meningkatkan hasil belajar peserta didik. Model pembelajaran inquiri merupakan inovasi-inovasi guru, kerjasama yang baik, bertanggung jawab terhadap tugasnya, mandiri, kemampuan tampil di depan teman-temannya, kemampuan berdiskusi, memberi kesempatan yang sama kepada setiap peserta didik sehingga unggul dalam prestasi, aktif dan kreatif.

Pembelajaran inkuiri berorientasi pada Pengembangan Intelektual (Andoko, 2020; Suparmi, 2019). Tujuan utama dari pembelajaran inkuiri adalah pengembangan kemampuan berpikir. Dengan demikian, pembelajaran ini selain berorientasi kepada hasil belajar juga berorientasi pada proses belajar. Prinsip Interaksi. Proses pembelajaran pada dasarnya adalah proses interaksi, baik interaksi antara siswa maupun interaksi siswa dengan guru, bahkan interaksi antara siswa dengan lingkungan. Pembelajaran sebagai proses interaksi berarti menempatkan guru bukan sebagai sumber belajar, tetapi sebagai pengatur lingkungan atau pengatur interaksi itu sendiri. Peran guru yang harus dilakukan dalam menggunakan pembelajaran ini adalah guru sebagai penanya. Sebab, kemampuan siswa untuk menjawab setiap pertanyaan pada dasarnya sudah merupakan sebagian dari proses berpikir (Gunantara, Suarjana, \& Riastini, 2019; Suratijo, 2015). Dalam hal ini, kemampuan guru untuk bertanya dalam setiap langkah inkuiri sangat diperlukan. Pembelajaran ini juga perlu dikembangkan sikap kritis siswa dengan selalu bertanya dan mempertanyakan berbagai fenomena yang sedang dipelajarinya. Tugas guru adalah menyediakan ruang untuk memberikan kesempatan kepada siswa mengembangkan hipotesis dan secara terbuka membuktikan kebenaran hipotesis yang diajukannya.

Melihat langkah-langkah model pembelajaran Inquiri yang ampuh dalam memecahkan masalah yang ada, yang lebih diyakini lagi dengan kebenaran teori yang disampaikan. Penelitian ini bertujuan untuk menganalisis pengaruh penerapan Model Pembelajaran Inquiri terhadap hasil belajar kimia kelas X IPA 4. Diharapkan model pembelajaran Inquiri dapat meningkatkan motivasi dan keaktifan siswa dalam belajar sehingga dapat meningkatkan hasil belajar siswa khususnya pada mata pelajaran Kimia.

\section{Metode}

Penelitian yang dilakukan termasuk penelitian tindakan kelas. Tujuan utama Penelitian Tindakan Kelas adalah untuk memecahkan permasalahan nyata yang terjadi di dalam kelas, juga sekaligus mencari jawaban ilmiah mengapa hal tersebut dapat dipecahkan dengan tindakan yang dilakukan. Rancangan penelitian tidakan kelas ini menggunakan model Kemmis dan Mc. Taggart. Subjek penelitian ini adalah semua peserta didik kelas X IPA 4 SMA Negeri 1 Kuta Utara tahun pelajaran 2017/2018. Dengan jumlah peserta didik 42 yang terdiri dari 12 peserta didik laki-laki dan 30 peserta didik perempuan. Objek penelitian ini adalah peningkatan hasil belajar peserta didik kelas X IPA 4 SMA Negeri 1 Kuta Utara setelah diterapkan model Inquiri dalam proses pembelajaran. Untuk mengumpulkan data penelitian ini digunakan tes hasil belajar peserta didik. Metode yang digunakan untuk menganalisis data hasil penelitian ini adalah metode deskriptif.

\section{Hasil dan Pembahasan}

Perencanaan siklus I yang sudah matang, dengan membuat RPP sesuai alur model pembelajaran inquiri lebih menuntun peserta didik mampu meningkatkan kemampuan belajarnya. Pada saat pelaksanaan, peneliti telah mengupayakan agar alur model pembelajaran inquiri berjalan sesuai harapan sehingga peserta didik betul belajar sesuai harapan model pembelajaran ini. Kendala yang masih ada adalah pola peserta didik baru mulai diupayakan belajar menggunakan model pembelajaran yang baru dimana para peserta didik mulai dituntut menemukan sendiri, sedangkan model pembelajaran yang lama 
masih sifatnya menyuapi. Karena model ini baru mulai dicobakan, para peserta didik masih tercengang memikirkan kebiasaan yang lama dimana mereka masih senang untuk disuapi. Pengamatan/observasi juga sudah berjalan sesuai harapan walaupun hasilnya belum memenuhi kriteria usulan penelitian mengingat peneliti baru mulai menggunakan model pembelajaran yang baru, dimana guru terkendala dalam merubah kebiasaan untuk tidak menceramahkan materi.

Nilai rata-rata yang diperoleh pada siklus II menunjukkan peningkatan dari siklus I yaitu dari 66,21 menjadi 81,31. Dari data ada 38 peserta didik mendapat nilai di atas rata-rata dan ada 4 peserta didik memperoleh nilai di bawah rata-rata. Peserta didik yang memperoleh nilai di bawah rata-rata akhirnya dibina kembali, diberi arahan-arahan, motivasi-motivasi, penguatan-penguatan agar mereka berupaya lebih baik. Secara keseluruhan hasil yang didapat telah memenuhi kriteria keberhasilan penelitian sehingga tidak diberikan lagi ke siklus berikutnya. Hasil yang diperoleh dari tes prestasi belajar di siklus II menunjukkan bahwa kemampuan peserta didik dalam mengikuti pelajaran sudah cukup baik. Ini terbukti dari rata-rata nilai peserta didik mencapai 81,31. Setelah dibandingkan nilai awal, nilai siklus I dan nilai siklus II, terjadi kenaikan yang signifikan, yaitu dari rata-rata nilai awal adalah 54,26 naik di siklus I menjadi 66,21 dan di siklus II naik menjadi 81,31. Kenaikan ini tidak bisa dipandang sebelah mata karena kenaikan nilai ini adalah dari upaya-upaya yang maksimal yang dilaksanakan peneliti demi peningkatan mutu pendidikan dan kemajuan pendidikan khususnya di SMA Negeri 1 Kuta Utara.

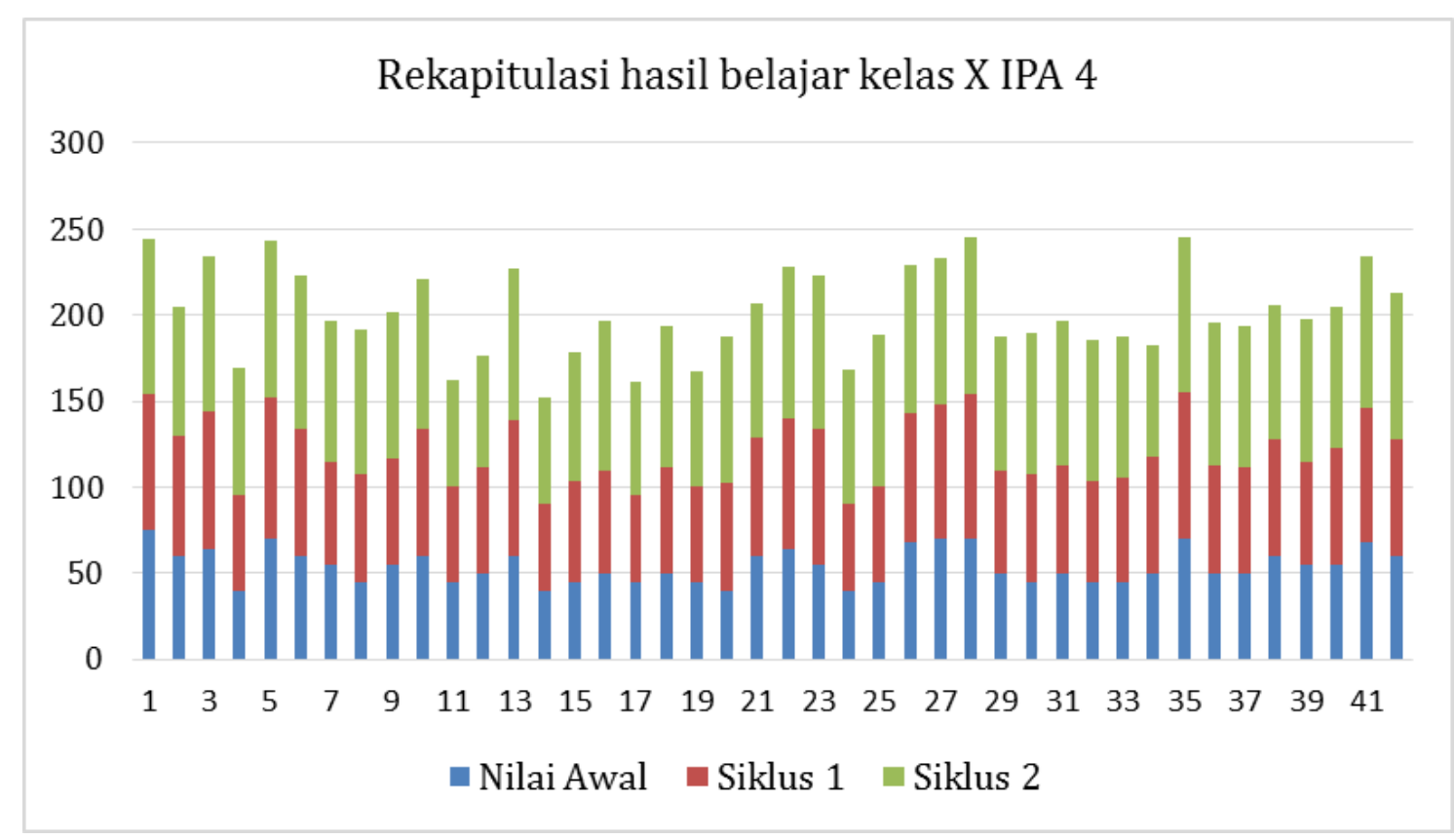

Gambar 1. Histogram Rekapitulasi Hasil Belajar Kelas X IPA 4.

. Hasil ini menunjukkan bahwa model pembelajaran inquiri telah berhasil meningkatkan kemampuan peserta didik menempa ilmu sesuai harapan. inquiri merupakan model yang cocok bagi peserta didik apabila guru menginginkan mereka memiliki kemampuan berkreasi, berargumentasi, mengeluarkan pendapat secara lugas, bertukar pikiran, berargumentasi, mengingat penggunaan model pembelajaran ini adalah untuk memupuk kemampuan berbicara dihadapan orang banyak. Hasil penelitian ini ternyata telah memberi efek utama bahwa model yang diterapkan dalam proses pembelajaran berpengaruh secara signifikan terhadap prestasi belajar peserta didik. Model pembelajaran inquiri dapat meningkatkan hasil belajar siswa disebabkan karena beberapa faktor yaitu sebagai berikut.

Pertama, dengan model pembelajaran inquiri berdampak pada kompetensi pengetahuan Kimia karena dapat keaktifan siswa dalam belajar. Temuan ini membuktikan bahwa guru sudah tepat memilih metode dalam melaksanakan proses pembelajaran karena pemilihan metode merupakan hal yang tidak boleh dikesampingkan. Hal ini sejalan pula dengan temuan-temuan peneliti lain yang menyatakan pada dasarnya menyatakan bahwa metode pembelajaran yang diterapkan berpengaruh terhadap prestasi belajar peserta didik (Kurnia, Damayani, \& Kiswoyo, 2019a, 2019b; Putri, Kusmariyatni, \& Murda, 2018). Mata pelajaran kimia menitikberatkan kajiannya pada aspek kognitif, psikomotor dan afektif sebagai pedoman atas kemampuan peserta didik baik pikiran, prilaku maupun keterampilan yang dimiliki (Ferdian, Maryam, \& Selamat, 2018; Redhana, 2019). Untuk semua bantuan terhadap hal ini, metode 
inquiri menempati tempat yang penting karena dapat mengaktifkan peserta didik secara maksimal. Dari nilai yang diperoleh peserta didik, lebih setengah peserta didik mulai aktif mengikuti pembelajaran di kelas. Dari perbandingan nilai ini sudah dapat diyakini bahwa hasil belajar peserta didik dapat ditingkatkan dengan penggunaan model pembelajaran inquiri. Model pembelajaran inquiri merupakan kegiatan pembelajaran yang melibatkan secara maksimal seluruh kemampuan siswa untuk mencari dan menyelidiki sesuatu (benda, manusia atau peristiwa) secara sistematis, kritis, logis, analitis sehingga mereka dapat merumuskan sendiri penemuannya dengan penuh percaya diri. Model pembelajaran inquiri mempunyai langkah-langkah yang mendorong keaktifan peserta didik dalam belajar dengan cara memberikan kesempatan bagi peserta didik untuk siap tampil dihadapan teman-temannya (Arifin, Kirana, \& Widodo, 2017; N. L. Dewi, Dantes, \& Sadia, 2013). Untuk mampu tampil dihadapan orang banyak bukanlah hal yang gampang. Untuk mampu menampilan sesuatu harus kerjasama yang baik didahului persiapan yang matang, belajar untuk menguasai materi yang akan disajikan (penguasaan keilmuan), berani berbicara dan mengemukakan pendapat (mental yang tinggi), menerima dorongan guru, motivasi guru.

Kedua, model pembelajaran inquiri berdampak pada kemampuan siswa dalam memecahkan masalah sehingga dapat meningkatkan kemampuan berpikir kritis pada siswa. Tujuan dari pembelajaran inkuiri adalah mengembangkan kemampuan berpikir secara sistematis, logis, dan kritis, atau mengembangkan kemampuan intelektual sebagai bagian dari proses mental. Dengan demikian, dalam pembelajaran inkuiri siswa tidak hanya dituntut untuk menguasai materi pelajaran, akan tetapi bagaimana mereka dapat menggunakan potensi yang dimilikinya (Citrawathi, Adnyana, \& Santiasa, 2016; Putri et al., 2018). Manusia yang hanya menguasai pelajaran belum tentu dapat mengembangkan kemampuan berpikir secara optimal. Sebaliknya, siswa akan dapat mengembangkan kemampuan berpikirnya manakala ia bisa menguasai materi pelajaran. Model pembelajaran inquiri ini dirancang agar siswa bisa melaksanakan segala eksperimen secara mandiri sehingga pengalaman siswa tentang ilmu pengetahuan bisa semakin luas. Hal tersebut bisa mendorong siswa untuk berpikir secara kreatif, logis, analitis, sistematis dan kritis, selain itu penerapan model inquiry bisa mendorong siswa untuk ke tingkat intelektual lebih tinggi. Pembelajaran inkuiri menekankan kepada proses mencari dan menemukan (Putra, Margunayasa, \& Wibawa, 2017; Wati, Susilo, \& Sutopo, 2018). Materi pelajaran tidak diberikan secara langsung. Peran siswa dalam pembelajaran ini adalah mencari dan menemukan sendiri materi pelajaran, sedangkan guru berperan sebagai fasilitator dan pembimbing siswa untuk belajar. Pembelajaran inkuiri merupakan rangkaian kegiatan pembelajaran yang menekankan pada proses berpikir kritis dan analitis untuk mencari dan menemukan sendiri jawaban dari suatu masalah yang dipertanyakan.

Ketiga, model pembelajaran inquiri ini mampu merangsang peserta didik untuk dapat bertanggung jawab terhadap pekerjaannya, menuntut persiapan yang sangat matang, menuntut kemampuan yang matang dalam presentasi, menutut semangat yang tinggi untuk mengikuti pelajaran agar dapat mempersiapkan tampilan yang diharapkan, menuntut sebab akibat dari pelaksanaan diskusi. Tanpa keilmuan yang mencukupi tidak akan mungkin tampilannya akan memuaskan, dalam hal ini peserta didik tidak bisa sembarangan saja, mereka harus betul-betul mampu menyimpulkan terlebih dahulu apa yang mereka akan bicarakan. Tuntunan langkah-langkah, motivasi, interpretasi yang inovatif dipihak guru akan menentukan keberhasilan pelaksanaan model ini. Model pembelajaran inquiri menuntut kemampuan peserta didik untuk giat mempelajari apa yang disampaikan guru, mampu menampilkan dirinya di depan peserta didik yang lain (Paramitha, Sulastri, \& Margunayasa, 2016; Widani, Sudana, \& Agustiana, 2019). Dipihak lain, untuk dapat menyelesaikan tuntutan tersebut, inovasi yang dilakukan guru akan sangat menentukan. Inovasi tersebut berupa tuntunan-tuntunan, motivasi-motivasi, interpretasi serta kemampuan implementasi yang tinggi. Cara inilah yang dapat digunakan sebagai dasar pemecahan masalah yang ada.

Keempat, dengan model pembelajaran inquiri berdampak pada hasil belajar siswa yang meningkat. Modle pembelajaran ini membuat siswa lebih mudah memahami materi pembelajaran yang disampaikan oleh guru (Muliani \& Wibawa, 2019; Paramitha et al., 2016). Pembelajaran inkuiri menekankan kepada aktivitas siswa secara maksimal untuk mencari dan menemukan. Dalam proses pembelajaran, siswa tidak hanya berperan sebagai penerima materi pelajaran melalui penjelasan guru secara verbal, tetapi mereka berperan untuk menemukan sendiri inti dari materi pelajaran itu sendiri. Seluruh aktivitas yang dilakukan siswa diarahkan untuk mencari dan menemukan jawaban sendiri dari sesuatu yang dipertanyakan, sehingga diharapkan dapat menumbuhkan sikap percaya diri (Juniati \& Widiana., 2017; Sentanu, Rasana, \& Kusmariyatni, 2013). Dengan demikian, pada pembelajaran inkuiri menempatkan guru bukan sebagai satu-satunya sumber belajar, tetapi lebih diposisikan sebagai fasilitator dan motivator belajar siswa. Aktivitas pembelajaran biasanya dilakukan melalui proses tanya jawab antara guru dan siswa. Karena itu kemampuan guru dalam menggunakan teknik bertanya merupakan 
syarat utama dalam melakukan inkuiri. Guru dalam mengembangkan sikap inkuiri di kelas mempunyai peranan sebagai konselor, konsultan, teman yang kritis dan fasilitator. Ia harus dapat membimbing dan merefleksikan pengalaman kelompok, serta memberi kemudahan bagi kerja kelompok.

Penelitian yang dilakukan oleh Muliani \& Wibawa (2019) menyatakan bahwa model pembelajaran Inkuiri dapat meningkatkan hasil belajar siswa. Penelitian yang dilakukan oleh Nurhabibah, Hidayat, \& Mudiono (2018) menyatakan bahwa model pembelajaran Inkuiri dapat meningkatkan minat siswa dalam belajar sehingga dapat meningkatkan prestasi siswa dalam belajar. Penelitian yang dilakukan oleh Carlucy, Suadnyana, \& Negara (2018) juga menyatakan bahwa model pembelajaran Inkuiri dapat meningkatkan kompetensi siswa. Berdasarkan penelitian ini maka dapat disimpulkan bahwa model pembelajaran Inkuri dapat meningkatkan kemampuan siswa dalam belajar sehingga meningkatkan hasil belajar siswa. Inkuiri merupakan bagian inti dari kegiatan pembelajaran berbasis kontekstual. Implikasi penelitian ini memberikan dampak meningkatkan keaktifan siswa dalam belajar dan menciptakan suasana pembelajaran yang menyenangkan, siswa dapat bekerja sama satu sama lain sehingga model ini dapat meningkatkan hasil belajar Kimia. Pengetahuan dan keterampilan yang diperoleh siswa diharapkan bukan hasil mengingat seperangkat fakta, melainkan hasil dari menemukan sendiri. Apabila peserta didik dapat mengaitkan isi dari mata pelajaran dengan pengalaman mereka sendiri, mereka bisa dikatakan menemukan makna dan makna memberi mereka alasan untuk belajar.

\section{Simpulan}

Model pembelajaran inquiri dapat meningkatkan motivasi serta keaktifan siswa dalam belajar sehingga berpengaruh pada peningkatan prestasi belajar pada siswa. Model pembelajaran ini dapat meningkatkan kerjasama, berkreasi, bertindak aktif, bertukar informasi, mengeluarkan pendapat, bertanya, berdiskusi, berargumentasi dan lain-lain.

\section{Daftar Rujukan}

Andoko. (2020). Peningkatan Hots Dan Prestasi Belajar Melalui Metode Inkuiri Kelas 7C SMPN 1 Wonosobo Tahun Pelajaran 2018/2019. Spektra: Jurnal Kajian Pendidikan Sains, 6(1). https://doi.org/https://doi.org/10.32699/spektra.v6i1.134.

Anika, \& Fajar. (2020). Efektivitas Model Pembelajaran Kooperatif Tipe Make-A Match Dalam Meningkatkan Kompetensi Sikap Siswa dan Kompetensi Pengetahuan Siswa Pada Pelajaran IPS. $\begin{array}{llll}\text { Jurnal Ilmiah Sekolah 80-85. } & \text { Dasar, }\end{array}$ https://doi.org/http://dx.doi.org/10.23887/jisd.v4i1.24047.

Ardiawan, I. K. N. (2020). Studi Peningkatan Kesiapan Guru Paud Terhadap Implementasi Kurikulum 2013 (Meta-Analisis). Widya Kumara: Jurnal Pendidikan Anak Usia Dini, 1(1). Retrieved from https://stahnmpukuturan.ac.id/jurnal/index.php/JPAUD/article/view/580.

Arifin, M. Y., Kirana, T., \& Widodo, W. (2017). Pembelajaran Inkuiri Terbimbing Untuk Meningkatkan Kemampuan Bernalar Siswa Kelas Vi Berbantuan Media Buku Pop Up. Jurnal Penelitian Pendidikan IPA, 2(1), 6-14. https://doi.org/http://dx.doi.org/10.26740/jppipa.v2n1.p6-10.

Budiartini, Arcana, \& Margunayasa. (2013). Pengaruh Model Pembelajaran Inquiri Terbimbing Terhadap Kemampuan Berpikir Kritis Ipa Siswa Kelas V Di SD 7 Datah. Mimbar PGSD Undiksha, 1(1). https://doi.org/http://dx.doi.org/10.23887/jjpgsd.v1i1.891.

Carlucy, Suadnyana, \& Negara. (2018). Pengaruh Model Pembelajaran Inkuiri Terbimbing Berbantuan Media Konkret Terhadap Kompetensi Pengetahuan IPA. Mimbar Ilmu Undiksha, 23(2), 162-169. https://doi.org/https://doi.org/10.23887/mi.v23i2.16416.

Citrawathi, Adnyana, \& Santiasa. (2016). Analisis Kebutuhan Untuk Pengembangan Modul Inkuiri Berbasis $\begin{array}{llll}\text { Pertanyaan. Jurnal Pendidikan Indonesia, } & \text { 5(1), }\end{array}$ https://doi.org/https://doi.org/10.23887/jpi-undiksha.v5i1.8289.

Damanik, \& Anggaraeni. (2018). Hubungan Persepsi Keterampilan Mengajar Guru dengan Motivasi Belajar Siswa Akselerasi di Sekolah Menegah Atas Al-Azhar Medan. Analitika: Jurnal Magister Psikologi UMA, 10(2), 60-68. https://doi.org/https://doi.org/10.31289/analitika.v10i2.1788.

Dewi, N. L., Dantes, N., \& Sadia, I. W. (2013). Pengaruh Model Pembelajaran Inkuiri Terbimbing Terhadap Sikap Ilmiah dan Hasil Belajar IPA. Jurnal Pendidikan Dasar Ganesha, 3(1). https://doi.org/10.19184/jpf.v6i2.5020. 
Dewi, R. S. (2018). Kemampuan Profesional Guru Dan Motivasi Kerja Terhadap Kinerja Mengajar Guru Sekolah Dasar. Jurnal Administrasi Pendidikan, 25(1), 150-158. https://doi.org/https://doi.org/10.17509/jap.v25i1.11581.

Febriana. (2017). Efektivitas Model Pembelajaran Berbasis Kompetensi Dengan Pendekatan Dunia Kerja Pada Program D3 Tata Boga. Cakrawala Pendidikan, 36(1), 148-155. Retrieved from https://journal.uny.ac.id/index.php/cp/article/view/8891/pdf.

Ferdian, A., Maryam, S., \& Selamat, I. N. (2018). Analisis Kesapan Belajar Siswa Kelas X Mipa Dalam Pembelajaran Kimia. Jurnal Pendidikan Kimia Undiksha, 2(1), 8. https://doi.org/10.23887/jjpk.v2i1.21177.

Fitriana, Lesmanawati, \& Maknun. (2014). Penerapan Pembelajaran Berbasis Inquiri Sederhana Untuk Meningkatkan Literasi Sains Siswa Pada Konsep Ekosistem Di Kelas X Ma Khas Kempek Cirebon. Scientiae Educatia: Jurnal Pendidikan https://doi.org/https://doi.org/10.24235/sc.educatia.v3i1.555.

Gunantara, G., Suarjana, M., \& Riastini, P. N. (2019). Penerapan Strategi Pembelajaran Problem Based Learning Untuk Meningkatkan Kemampuan Pemecahahan Masalah Matematis Siswa Kelas IV. $\begin{array}{llll}\text { Kreano, Jurnal Matematika 10(2), Kreatif-Inovatif, 146-152. } & \text { 10 }\end{array}$ https://doi.org/10.15294/kreano.v10i2.19671.

Jaedun, \& Nuryadin. (2017). Dampak Pengiring Pembelajaran Pendekatan Saintifik untuk Pengembangan Sikap Spiritual Dan Sosial SiswaJaedun, \& Nuryadin. (2017). Dampak Pengiring Pembelajaran Pendekatan Saintifikuntuk Pengembangan Sikap Spiritual Dan Sosial Siswa. Cakrawala $\begin{array}{llll}\text { Pendidikan, } & \text { 36(1), } & \text { Retrieved } & \text { from }\end{array}$ https://journal.uny.ac.id/index.php/cp/article/view/12792/pdf.

Juniati, \& Widiana. (2017). Penerapan Model Pembelajaran Inkuiri Untuk Meningkatkan Hasil Belajar IPA. Jurnal Ilmiah Sekolah Dasar, 20-19. https://doi.org/http://dx.doi.org/10.23887/jisd.v1i1.10126.

Kristiantari, M. R. (2015). Analisis kesiapan guru sekolah dasar dalam mengimplementasikan pembelajaran tematik integratif menyongsong kurikulum 2013. JPI (Jurnal Pendidikan Indonesia), 3(2). https://doi.org/http://dx.doi.org/10.23887/jpi-undiksha.v3i2.4462.

Kurnia, Damayani, \& Kiswoyo. (2019a). Keefektifan Model Pembelajaran Number Head Together (NHT) Berbantu Media Puzzle Terhadap Hasil Belajar Matematika. Jurnal Ilmiah Sekolah Dasar, 3(2), 192. https://doi.org/https://doi.org/10.23887/jisd.v3i2.17772.

Kurnia, V. T., Damayani, A. T., \& Kiswoyo, K. (2019b). Keefektifan Model Pembelajaran Number Head Together (NHT) Berbantu Media Puzzle Terhadap Hasil Belajar Matematika. Jurnal Ilmiah Sekolah Dasar, 3(2), 192. https://doi.org/10.23887/jisd.v3i2.17772.

Muliani, N. K. D., \& Wibawa, I. M. C. (2019). Pengaruh Model Pembelajaran Inkuiri Terbimbing Berbantuan Video Terhadap Hasil Belajar IPA. Jurnal Ilmiah Sekolah Dasar, 3(1), 107-114. https://doi.org/10.31539/spej.v2i1.333.

Nurhabibah, S., Hidayat, A., \& Mudiono, A. (2018). Pengaruh Model Pembelajaran Inkuiri Terbimbing Terhadap Keterampilan Proses Sains dan Hasil Belajar Muatan IPA di Kelas IV. Jurnal Pendidikan: Teori, Penelitian, Dan Pengembangan, 3(10), 1286-1293. https://doi.org/10.20414/jb.v8i1.56.

Oktiani, I. (2017). Kreativitas Guru dalam Meningkatkan Motivasi Belajar Peserta Didik. Jurnal Kependidikan. https://doi.org/10.24090/jk.v5i2.1939.

Paramitha, I. D. A. A., Sulastri, M. P., \& Margunayasa, I. G. (2016). Pengaruh Model Inkuiri Terbimbing, Gaya Kognitif, dan Motivasi Berprestasi terhadap Pemahaman Konsep IPA Siswa Kelas V SD. MIMBAR PGSD Undiksha, 4(1), 1-11. https://doi.org/10.23887/jppundiksha.v49i2.9012.

Putra, Margunayasa, \& Wibawa. (2017). Pengaruh Model Pembelajaran Inkuiri Terbimbing Berbantuan Peta Pikiran terhadap Hasil Belajar IPA Kelas V SD. MIMBAR PGSD Undiksha, 5(2), 1-10.

Putri, N. P. L. K., Kusmariyatni, N., \& Murda, I. N. (2018). Pengaruh Model Pembelajaran Inkuiri Terbimbing Berbantuan Media Audio-Visual Terhadap Hasil Belajar IPA. Mimbar PGSD, 6(3), 153-160.

Rani, Ardana, \& Negara. (2019). Pengaruh Model Pembelajaran Talking Stick Berbantuan Lagu Tradisional Terhadap Kompetensi Pengetahuan IPA. Jurnal Mimbar Ilmu, 24(3). 
https://doi.org/http://dx.doi.org/10.23887/mi.v24i3.21676.

Redhana, I. W. (2019). Mengembangkan Keterampilan Abad Ke-21 Dalam Pembelajaran Kimia. Jurnal Inovasi Pendidikan Kimia, 13(1), 2239-2253. Retrieved from https://journal.unnes.ac.id/nju/index.php/JIPK/article/view/17824.

Rediasih, Suwatra, \& Putri. (2019). Pengaruh Model Pembelajaran Debate Terhadap Keterampilan Berbicara Pada Mata Pelajaran Bahasa Indonesia Siswa Kelas V. Jurnal Mimbar PGSD Universitas Pendidikan Ganesha, 5(2). https://doi.org/https://ejournal.undiksha.ac.id.

Renny, Sonbay, Yohana, R. (2019). the Effect of Open-Ended Teaching Model on Mathematics. Jurnal Kependidikan Matematika, 1(2), 105-110. Retrieved from https://journal.unwira.ac.id/index.php/ASIMTOT.

Sentanu, I. M., Rasana, I. D. P. R., \& Kusmariyatni, N. (2013). Pengaruh Model Pembelajaran Inkuiri Terbimbing Terhadap Hasil Belajar IPA Siswa Kelas V SD Negeri di Sambirenteng. MIMBAR PGSD Undiksha, 1(1).

Sukarmen. (2019). Upaya Meningkatkan Prestasi Siswa Terhadap Mata Pelajaran Pembibitan Tanaman Dengan Materi Pokok Pembiakan Tanaman Secara Vegetatif Melalui Penerapan Metode $\begin{array}{llll}\text { Pembelajaran } \quad \text { Berbasis Inquiri. } & \text { Mimbar }\end{array}$ https://doi.org/http://dx.doi.org/10.23887/mi.v24i3.21681.

Sumiarta, Murda, \& Rati. (2013). Pengaruh Model Pembelajaran Telaah Yurisprodensi Inquiri Terhadap Hasil Belajar Pkn Sd Kelas V Semester Ii Di Gugus IV Kecamatan Kintamani. Mimbar PGSD Undiksha, 1(1). https://doi.org/http://dx.doi.org/10.23887/jjpgsd.v1i1.1337.

Suparmi, N. W. (2019). Hasil Belajar Pemahaman Konsep Dan Berpikir Kreatif Siswa Dalam Pembelajaran Inkuiri Bebas Dan Inkuiri Terbimbing. Journal of Education Technology, 2(4), 192. https://doi.org/10.23887/jet.v2i4.16548.

Suratijo. (2015). Pengaruh Penggunaan Metode Pembelajaran Inkuiri Dan Aktivitas Belajar Terhadap Hasil Belajar Siswa Kelas X Di SMA N 1 Penengahan Tahun Pelajaran 2013/2014. Bioedukasi: $\begin{array}{lllll}\text { Jurnal Pendidikan Biologi } & \text { FKIP } & \text { UM }\end{array}$ https://doi.org/https://doi.org/10.24127/bioedukasi.v6i2.337.

Wahyono, P., Husamah, H., \& Budi, A. S. (2020). Guru profesional di masa pandemi COVID-19: Review implementasi, tantangan, dan solusi pembelajaran daring. Jurnal Pendidikan Profesi Guru, 1(1), 51-65. https://doi.org/https://doi.org/10.22219/jppg.v1i1.12462.

Wati, A., Susilo, H., \& Sutopo. (2018). Pengaruh Pembelajaran Inkuiri Terbimbing Berbantuan Jurnal Belajar terhadap Penguasaan Konsep IPA Siswa. Jurnal Pendidikan.

Widani, N. K. T., Sudana, D. N., \& Agustiana, I. G. A. T. (2019). Pengaruh Model Pembelajaran Inkuiri Terbimbing Terhadap Hasil Belajar IPA Dan Sikap Ilmiah Pada Siswa Kelas V SD Gugus I Kecamatan Nusa Penida. Journal of Education Technology, 3(1), 15-21. https://doi.org/10.23887/jet.v3i1.17959

Widiartini, P. D. O., Putra, M., \& Manuaba, S. (2018). Pengaruh Model Pembelajaran Group Investigation Berbasis Tri Hita Karana Terhadap Kompetensi Pengetahuan IPA. Jurnal Ilmiah Sekolah Dasar, 3. https://doi.org/http://dx.doi.org/10.23887/jisd.v3i3.19476.

Wulandari, Sudatha, \& Simamora. (2020). Pengembangan Pembelajaran Blended Pada Mata Kuliah Ahara Yoga Semester II di IHDN Denpasar. Jurnal Edutech Undiksha, 8(1), 1-15. https://doi.org/http://dx.doi.org/10.23887/jeu.v8i1.26459. 